\title{
The North Carolina Libraries Centennial Oral History Project
}

\author{
by Thomas Kevin B. Cherry
}

ibraries and librarians have been among the chief promoters and supporters of oral history programs. Not only have they collected, preserved, and made accessible the taped interviews conducted by microphone-toting historians, but, in a great many cases, libraries and librarians actually have been the sponsors of oral history projects and programs. In some notable instances, it has been the librarian wielding the microphone. Over the years, libraries have teamed oral history with everything from bookmobile service to children's programming, classroom projects, and local history and genealogy activities.

While libraries have for generations worked hard to document the activities of the individuals and communities that they serve, they have not always been as active in documenting the story of their own institutions or the work of their colleagues at the circulation desk or in the stacks. The "story" of local libraries might be relegated to a paragraph at the beginning of a major report or on an interior page of a Web site, while the role played by individual librarians in the lives of their communities is often summed up in a subordinate clause in the midst of an obituary: "serving as children's librarian for 27 years." Despite librarianship's support of oral history programs, in general, there have been very few oral history projects that have attempted to document the library profession. ${ }^{1}$ This needs to be addressed.

With the Centennial of the North Carolina Library Association quickly approaching, the committee charged with commemorating that milestone readily agreed that a North Carolina library oral history project should be attempted. Although they were excited by the prospect, the committee members also were a bit apprehensive. Any oral history project is laborintensive. With that in mind, the committee members decided to seek partners across the state, inviting local librarians to tape interviews with individuals who have contributed much to their local institutions. Hearing that this was the plan, librarians from around North Carolina asked for guidance, and the committee developed an interview guide for the project. This guide was developed especially to gather those stories that might not make local newspaper accounts or library board minutes. The History Committee of the Centennial Conference especially wanted to capture the story of North Carolina's African American branches during segregation and library services and librarians adapting to new technologies (retrospective conversion, public access to the Internet, etc.) At the same time, the committee members hoped 
that more local and individual stories might be documented: the successful (or unsuccessful) library bond referendum campaign, why a local library leader chose to work in libraries, etc.

What follows is the guide that was developed for the North Carolina Libraries Centennial Oral History Project, along with the associated oral history permission form. Local libraries are encouraged to audiotape or videotape interviews with local librarians, keep the originals, and donate copies to the North Carolina Library Association's archives for the use of future researchers interested in library topics. Remember, oral history interviewees do not have to be elderly or even senior members of the community. Copies of interviews may be donated to NCLA's centennial project by contacting the author at: cherryt@mail.ecu.edu.

For further guidance in oral history interview practices, interviewers might wish to consult the Web site of the Southern Oral History Program at the University of North Carolina at Chapel Hill, http://www.sohp.org/. The Regional Oral History Office at the Bancroft Library of the University of California, Berkeley has a good list of resources on its Web site, including a bibliography and interview tips, http://bancroft.berkeley.edu/ROHO. The University of California, Los Angeles (UCLA) also sponsors a useful oral history Web site located at http://www.library.ucla.edu/libraries/special/ohp/ ohpbib.htm.

\section{References}

${ }^{1}$ For examples of some recent articles concerning library oral history, see Sheue-fang Song and Shr-ying Shu, "Save the Memory: The Study of Oral History," Library Journal of Educational Media and Library Science 40 (June 2003): 497-511; and Helen Dalrymple, "Library Voices: Oral History Project Tells Tales of the Institution," Library of Congress Information Bulletin 62 (June 2003): 142-43.

\section{NCLA Centennial Celebration Oral History Interview Guide}

Remember: This is not a script. Not every question is appropriate for every interviewee. Interviewers should use this Guide in the creation of their own lists of questions. The interviewer should elicit stories and anecdotes. Interviewers should keep their comments as brief as possible while encouraging the interviewees to spin reminiscences.

\section{Before the Interview Begins}

- Choose a quiet location with the television and any other background sounds at a minimum. (Kitchen tables away from appliances tend to work well with audiotapes. The tape recorder has a place to sit between interviewer and interviewee.)

- Check your equipment; make sure it works, and, if it doesn't plug in, make sure you have extra batteries. Test your equipment on site. If you are using videotape, ask, "Is the lighting right?" Tape a bit, rewind, check audio and video levels.

- Have a pen in hand and be prepared to scribble one-word reminders to yourself during the interview for possible follow-up questions that occur while the interviewee is speaking.

- Before taping, engage in a bit of non-taped chit-chat.

- During this chit-chat, the interviewer explains to the interviewee that this oral history interview is a part of the observance of the NCLA Centennial and that the audiotape and/or videotape of the interview will be donated to the NCLA archives, which are kept by the State Archives of North Carolina. 
The interviewer will inform the interviewee that

— the tapes will be made available to researchers who are interested in North Carolina library issues.

— there are no right and wrong answers to the questions that will be asked. He or she might say, "We are interested in your opinions and what you can remember about your life in libraries."

- "I have a pen, and during the interview, I may scratch a note to myself while you are talking. This will just mean that you have said something that I might want to ask you more about later. Of course, you might answer my written question in the next breath, and I'll not need that note. So, don't think too much about my scribbling today."

— the interview will last no longer than an hour or so, but that "We are in no rush. If we have to, we can come back. So, we'll all just take our time."

- it is just fine for the interviewee to offer stories or information about something we may not have a question about.

Be prepared to LISTEN and ask follow-up questions. Do not simply go down your list of prepared questions, ticking them off. Think of your list of questions as simply starting points. It is possible that you will use very few of the queries you prepared ahead of time.

\section{Dating the Tape}

With the tape running, note the date, location, and subject of the interview. For example, you might say something like: "Today is March 12, 2004, and I am Joe Smith. Today, I am interviewing Sarah Johnson in her home on Maple Street in Greensboro, and we are going to talk about some of her library memories."

\section{Background Questions}

[To begin with, the interviewer asks two or three background questions to help the interviewee get over any jitters he or she might have and to get accustomed to the process. In this section, interviewers generally ask questions about childhood, growing up, etc. However, if the interviewer senses that the interviewee is reluctant to talk about any of these types of items, quickly change the focus of the initial questions. Instead, ask about retirement, hobbies, etc. - anything easy to talk about. The point of these "background" questions is to allow the interviewee to get comfortable. Do not spend too much time on these questions. When the interviewer senses that the interviewee is comfortable, quickly transition into the next set of questions by saying something like, "Well, let's turn to your library memories."]

We always like to start these sorts of interviews with a few background questions. They help us all get settled. So, let's begin with a bit of background. Tell me about where you grew up. [Pick up on something related in the answer to the above; ask a follow-up or two.]

or

How have you been enjoying your retirement? [Pick up on something related in the answer to the above; ask a follow-up or two.]

Transition: "Now, let's turn to your library memories."

\section{Discovering Libraries}

(Remember to listen to the responses, ask follow-ups, and go with the flow.)

Tell me about the library you visited as a child.

Describe the facility.

How often would you get to go to the library?

What sorts of things would you do in the library as a child?

Would you use the library for schoolwork?

How?

What were the librarians there like?

Tell me about any librarians from those days that might stand out in your memory now. 
What sorts of books were your favorites as a child?

Did you have an absolute favorite book as a child?

Tell me about some of the library rules and regulations that you remember from your childhood.

Were there sections of the library or books that children were not allowed to go into?

Were you ever tempted?

If someone had asked you when you were a child what a librarian did, what would you have told them?

When you were in high school, what did you want to be when you grew up?

If someone had told you in high school that you would one day be a librarian, what would you have thought?

Have you ever returned as an adult to the library of your childhood?

\section{Becoming a Librarian}

(Remember to listen to the responses, ask follow-ups, and go with the flow.)

What were you doing when you decided to become a librarian?

How did you decide on librarianship as a profession? [Variant: Why did you want to become a librarian?]

[This is a perfect place for a series of follow-up questions.]

What did you know about the profession when you made this decision?

Was there one person who had more influence than others in leading you to this decision?

Tell me about her [or him].

We all know the librarian stereotype. What impact or effect do you think this stereotype had, if any, on your decision to join the profession?

What did your family think of your choice of profession?

What did your friends think of your career choice?

How did you find out that you needed to go to library school to be a librarian?

Where did you go to library school?

How did you decide to go to that particular library school?

Describe what library school was like for you. [This is a perfect place for a series of follow-up questions.]

What classes did you enjoy the most?

What classes did you enjoy the least?

Tell me about some of the library school instructors who stand out in your memory all these many years later.

Tell me about a project or paper from those days.

Looking back, what would you say was the major focus or emphasis of your library school training?

What friends did you make during library school whose friendship carried on through your career?

How well did library school prepare you for your career?

What could have been better about your library training?

\section{Being a Librarian}

(Remember to listen to the responses, ask follow-ups, and go with the flow.) [In this section, the interviewer attempts to obtain a history of the interviewee's professional life by asking questions that track the person's career. Answers to these questions will also give information about librarianship beyond one person's worklife.]

Tell me about your first library job.

[This is a perfect place for a series of follow-up questions.]

How did you get your first library position?

About when did you begin working in your first library?

What sort of work were you hired to do? Did you like it? 
Tell me about your co-workers.

Tell me about your "boss" or supervisor.

Describe the first library building you worked in.

How large was the building?

Did it have a distinctive smell?

What did the reference desk/children's area, etc. look like?

Where did technical services type activities take place?

Tell me about the library staff when you first started working?

How much use did the library get in those days?

When was the library's busiest time?

Characterize your library users from those days.

What sorts of expectations did average citizens in your community have regarding librarians when you first started?

What was your work schedule like when you first began? [Variant: Describe an average working day from the first of your career.]

What sort of audiovisual materials, if any, did your library have or support in those days?

What sort of special challenges (or headaches) for the library did this AV material provide?

How did your library handle its cataloging then?

What was your materials budget like when you first started? [Variant: Roughly, how many materials do you think your library added each year during the first days of your career?]

Tell me what reference service was like when you first started.

Tell me about how your library weeded its collection during the first years of your career.

Did this change over time?

What sort of programming would the library sponsor in those days?

What sorts of activities or services would you say your first library prided itself on during the first years or your profession?

What were some of the challenges that this library faced?

How did you seek to address those challenges?

What were some of the major issues facing libraries when you first started working?

[This is a perfect place for a series of follow-up questions.]

What was your stance on this issue?

Who were the leaders in the debate?

Do you think this is still a relevant issue today?

How well did you like this job?

What could have made the position better?

What led to your leaving this position?

\section{Transition Between Positions/Libraries}

[When the interviewee has exhausted his or her stories about that first library or position, transition and then repeat variants of the questions above. Follow the career. You will spend more time on some libraries or positions more than others. That is fine. Take your time. This is where most individuals want to skip right to their most interesting stories. If this is the case, you might explain what you are doing.]

Now, where did you work after "such-and-such" library? [Variant: What position did you take after that?]

\section{Closing Question for "Being a Librarian"}

Now, did you have any other jobs in the library that we may not have talked about? [Variant: Did we talk about all of the libraries you were associated with?] 


\section{Individualized Questions - Depending Upon the Interviewee}

The interviewer knows the interviewee better than does the writer of this guide - or, the interviewer has performed a bit of quick research to learn about some specific aspects of the interviewee's career before the interview takes place. For example, the interviewee may have been the founder of Public Library Quiz Bowl or she may have led a famous study of librarian salaries or she may have been president of the American Library Association (ALA). Before the interview, the interviewer should prepare a list of questions based upon the interviewee's own library/professional experience and ask them during or following the "Being a Librarian" section. What follows are only a few examples of some individualized questions. Depending upon the experience of the interviewee, some of the genres of questions might include the following:

\section{Libraries and Race}

(Remember to listen to the responses, ask follow-ups, and go with the flow.) Describe the library facilities that were provided for African Americans in your community before desegregation.

How would the local African American library facility get its materials? Was there any difference in the type of materials collecting by the African American branches as opposed to the White branches?

Tell me about the persons who worked in the local African American branch.

Who were the primary users of the local African American branch? What sort of support did the African American community provide their library?

How much interaction was there between African American and White branches of library systems?

How did African Americans first start to use the previously designated White library facilities?

What sort of opposition was there to African Americans using the White library facilities?

What sort of opposition was there to having African American employees working with White employees?

When the staffs were desegregated, what positions were given to the African Americans in the desegregated facilities?

How did the two library staffs get along together after their facilities merged?

How did the White users respond to having a Black library staff member? How long do you think it took before White employees in the library became comfortable with Black users?

Were there ever any instances where someone came to your library and was refused service library because of his or her race?

What was the worst part of having a segregated library system?

While segregation was wrong, was there any benefit to having a library facility set aside for African Americans?

Tell me about the way the North Carolina Negro Library Association merged with the North Carolina Library Association.

Who were some of the leaders in that effort?

Describe the debate that occurred about the merger of the two organizations. [Variant: Was this an issue that people felt strongly about?]

What did you think about the merger at the time?

\section{Libraries and Technology}

(Remember to listen to the responses, ask follow-ups, and go with the flow.) What was considered the newest, cutting-edge technology when you were in library school? 
How did that work?

Describe it for me.

How did you feel about this technology?

Why do you think it eventually was dropped (or incorporated) into the library?

What was the first type of new library technology that came out while you were working?

How did that work?

Describe it for me.

How did you feel about this technology?

Why do you think it eventually was dropped (or incorporated) into the library?

What did you think about it?

Tell me about the first time you ever saw a computer?

Tell me about when you first used a computer?

Describe your library's first computer.

Where did your library keep its first computer?

Why did your library decide to get a computer?

What did your first library use a computer for?

Did your users have access to the computer?

Who decided that your library should look in to using a computer?

Where did the money come from for the computer?

What sort of attitude did most people in your library have toward this first computer?

How well did you take to the computer?

What sort of training did you receive to use these computerized library tools?

Was the computer difficult to maintain?

How would you get it fixed?

During those first days with micro-computers, how did you think they might change libraries?

Tell me about any special rules your library may have had with that early, non-Internet computer?

Whatever happened to that first computer your library had?

What was the most difficult part of the transition to a computerized library?

What was your library's experience with compact discs as information sources?

Tell me about your library's experience with retrospective conversion.

[This is a perfect place for a series of follow-up questions.]

What do you think was the greatest argument for retrospective conversion?

How long did it take?

About when did you start?

What sort of planning was involved?

Where did the money come from for the conversion?

What library served as a model or guide in your retrospective conversion?

What sort of bumps did you find in the process?

How did your fellow co-workers respond to the new online catalog?

What did your users think of the new online catalog?

Do you think our libraries lost anything when they discarded the card catalog?

Tell me about bringing the Internet to your library.

[This is a perfect place for a series of follow-up questions.]

Why did you decide to offer public access to the Internet in your library?

What other library, if any, did you use as a model for bringing the

Internet to your library?

Tell me about the people who used these Internet computers when your 
library first introduced the service?

Have the users of the Internet computers changed over time?

What sort of special training did you offer the public to help with their use of the Internet?

What were some of your misgivings about the Internet in the library?

Were they substantiated?

How did you handle concerns over underage use of the Internet.

How did you derive your Internet policy?

Where did the money come from for the Internet?

Who was the one who really promoted public access to the Internet in your library?

Tell me about your library's first Web site.

What did it look like?

Who did it?

What kind of information did it carry?

How is it different now?

How do you think the computer has changed library service?

Would you say that you readily embraced new technology during your working life?

Service to the Profession: NCLA or ALA, etc.

(Remember to listen to the responses, ask follow-ups, and go with the flow.)

How did you become involved in [the organization]?

Why did you choose to become active in this area?

Who would you say were your mentors in [this organization]?

What were some of the issues that [the organization] was dealing with

when you first joined?

How would you characterize the leadership of [the organization] when you became active in it?

How did you come to run for office?

Why did you agree to run?

What did you hope to accomplish as an officer?

Tell me about what happened while you were an officer.

What was your biggest challenge as an officer?

[This is a perfect place for a series of follow-up questions.]

What was the most lasting contribution do you think [the organization]

made to the profession during your tenure as one of its leaders?

What were your favorite parts of [the organization's] conference?

Was there one informal or social event that you looked forward to at conferences?

Every organization has minor controversies and difficult times. As you look back, what were some of these for [the organization].

How did being a member of [the organization] affect your career?

Specific events (great stories come from the recounting of specific events) (Remember to listen to the responses, ask follow-ups, and go with the flow.) Examples, each of which could be expanded to be a whole section of interviews:

I know that you were instrumental in passage of the local bond referendum that ultimately paid for the new main library. Tell me about what all went in to that bond campaign.

Tell me about the merger of the community branches into regional branches.

Tell me about your first time behind the wheel of the bookmobile.

\section{General "Being a Librarian" Questions}

[These are the stories that might come out in the previous questioning — or they may be the ones that interviewees will want to skip to immediately.] 
Every library has individuals in county or college administration or persons in the community who are strong library supporters and who aid libraries greatly. Tell me about a non-librarian who had a great impact on your library.

Some libraries have experimented with the idea of circulating all types of materials, toys, for example. Did your library ever flirt with this type of circulation?

Just about every librarian has an "I-can't-believe-they-did-that-in-thelibrary" story. Do you have one you can share?

Just about every library is offered some gift that doesn't fit its collection but which is awkward to turn down. Do you have an example from your working days? Tell me about it.

Did you ever face a book challenge or attempt at censorship during your career?

What happened?

How did you respond?

What was the most significant gift made to your library while you were there?

How did your first promotion come about?

How was your new position different from the one you held before?

Tell me about your experience with Friends organizations.

What was your book sale like?

Describe any idiosyncrasies that your library (system, department, branch, etc.) might have had compared to other libraries?

There are not that many wealthy librarians in the world. Why do you suppose we haven't ever been paid any better?

What sort of community activities were you involved in outside of the library?

\section{Culminating Questions: The Most Important Questions?}

(Remember to listen to the responses, ask follow-ups, go with the flow.)

Is there some person who is North Carolina library related who we really don't want to forget? Someone you knew who really did a great deal for our profession and should not be overlooked?

[This is a perfect place for a series of follow-up questions.]

Anyone else?

What skill or ability do you think a person must have to be a good librarian?

Over your career, what proved to be the most difficult part of working in libraries?

What was the greatest professional joy you experienced during your years as a librarian?

What do you think had the greatest impact on libraries during your working years?

Which of your many skills and abilities do you think you relied upon the most during your working days?

What do you feel was your greatest contribution during your years as a librarian?

What was the greatest change you saw in the profession during your years as a librarian?

If you had not worked in libraries, what other career do you think you might have pursued?

Do you think library users have changed their expectations for library services over the years?

What one professional decision would you go back and change, if you could?

What do you think has been the most significant contribution of the 
libraries you have been connected with?

What do you think libraries could do better to meet the needs of their communities?

\section{Final Questions}

Is there anything that you would like to tell me that I have not asked you a question about?

Is there some part of your life in libraries that you think we might have given too little attention to?

Any words of wisdom you'd like to leave with us?

\section{After the Interview}

- Reassure the interviewee. Tell him or her what a good interview they have given and how useful it will be to those interested in library matters.

- Thank the interviewee.

- Make sure all tapes are labeled with the interviewer's and interviewee's names and the date along with "NLCA Centennial Oral History." Do this on site before you pack up.

- Both the interviewee and the interviewer should sign the oral history release form.

- Within the week, the interviewer should send a thank you note to the interviewee.

\section{NCLA Oral History Agreement}

I (We), NAME(S): of

ADDRESS:

CITY: STATE: ZIP:

TELEPHONE:

(H)

FAX: E-MAIL:

do hereby donate to the North Carolina Library Association all property and/or literary rights that I may possess in the oral history material listed below without restriction. I (We) understand that the said interview and all transcriptions thereof shall become the property of the North Carolina Library Association, which shall maintain them for the benefit of researchers. Access to the tape recording (including verbatim or respondent edited transcripts) shall be available for research purposes commencing 2004.

Description of property:

number of recording(s) in [cassette, DVD, video, CD-ROM] media form, resulting from [number] oral history interview session(s) lasting approximately [number] hour(s) with the interviewee(s), conducted

on [date] relating to

$$
\text { [subject discussed] }
$$

Donor(s) Signature

Oral History Interviewer(s) Signature
Date

Date 